\title{
Role of platelet chemokines, PF-4 and CTAP-III, in cancer biology
}

\author{
Katerina Pilatova ${ }^{1,6}$, Kristina Greplova', Regina Demlova ${ }^{2,5,6}$, Beatrix Bencsikova ${ }^{3}$, Giannoula Lakka Klement ${ }^{4,6}$ \\ and Lenka Zdrazilova-Dubska ${ }^{1,5,6^{*}}$
}

\begin{abstract}
With the recent addition of anti-angiogenic agents to cancer treatment, the angiogenesis regulators in platelets are gaining importance. Platelet factor 4 (PF-4/CXCL4) and Connective tissue activating peptide III (CTAP-III) are two platelet-associated chemokines that modulate tumor angiogenesis, inflammation within the tumor microenvironment, and in turn tumor growth. Here, we review the role of PF-4 and CTAP-III in the regulation of tumor angiogenesis; the results of clinical trial using recombinant PF-4 (rPF-4); and the use of PF-4 and CTAP-III as cancer biomarkers.
\end{abstract}

Keywords: Platelet, PF-4, CTAP-III, Cancer, Angiogenesis, IL-8, Inflammation

\section{Introduction}

Angiogenesis regulators are sequestered in platelets [1]. Platelet factor 4 and Connective tissue activating peptide III constitute two major platelet CXC chemokines [2]. CXC chemokines have four highly conserved cystein residues with the two $\mathrm{N}$-terminal cysteines separated by one amino acid residue. CXC chemokines are subdivided into two classes, ELR ${ }^{+}$and ELR ${ }^{-}$, based on the presence or absence of specific amino acid sequence (ELR, Glu-Leu-Arg) [3]. CXC chemokines are generally implicated in inflammatory angiogenesis, and the ELR motif plays an important role in whether the specific CXC chemokine promotes or inhibits angiogenesis. ELR-containing chemokines, such as CTAP-III, are pro-angiogenic, while ELR-lacking chemokines, such as PF-4 are angiostatic [3-5].

The following is a review of the role of PF-4 and CTAPIII in inhibition and regulation of tumor angiogenesis, respectively; results from rPF-4 clinical trial; and PF-4 and CTAP-III as cancer biomarkers.

\section{PF-4 physiology and function}

PF-4 is heparin-binding polypeptide belonging to the ELR CXC chemokine family. PF-4 is a tetrameric molecule,

\footnotetext{
* Correspondence: dubska@mou.cz

${ }^{1}$ Department of Laboratory Medicine, Masaryk Memorial Cancer Institute,

Zluty kopec 7, Brno 656 53, Czech Republic

${ }^{5}$ Department of Pharmacology, Medical Faculty, Masaryk University,

Kamenice 5, Brno 625 00, Czech Republic

Full list of author information is available at the end of the article
}

with each subunit consisting of 70 amino acid residues with molecular weight $7.8 \mathrm{kDa}[6]$. The human gene encoding PF-4 maps to 4q12-21 [7]. PF-4 is synthesized almost exclusively by megakaryocytes and sequestered in platelet $\alpha$-granules [8]. Upon activation, platelets release tetrameric PF-4 bound to two molecules of chondroitin sulphate proteoglycan, which is displaced by heparin binding [9]. Physiological platelet levels of PF-4 have been reported about $7-22$ ng PF- $4 / 10^{6}$ cells $[10,11]$ which is about $150 \mu \mathrm{g} / \mathrm{ml}$. Plasma levels of PF-4 are strongly dependent on platelet activation in vitro [10-14]; e.g. the levels in plasma supplemented by inhibitors of platelet function are as low as $1.8 \pm 1 \mathrm{ng} / \mathrm{ml}$ [13], while levels of PF-4 measured in citrated tubes can be as high as 150 $360 \mathrm{ng} / \mathrm{ml}(10,14)$. Similarly, high serum levels (about $5 \mu \mathrm{g} / \mathrm{ml}$ ) correlate with platelet counts [13].

PF-4 shows both procoagulant and anticoagulant activity. It can prevent heparin binding to antithrombin leading to inhibition of heparin-dependent thrombin inactivation [15]. On the other hand, the inhibition of factor XII (intrinsic or contact activation pathway) and that of vitamin K-dependent coagulation factors can lead to PF4-mediated anticoagulant activity [16,17]. PF-4 further inhibits coagulation by generation of activated protein $\mathrm{C}$ by thrombomodulin binding [18]. In addition to its function in thrombosis and hemostasis, PF-4 plays an important role in wound healing, atherosclerosis and tumor biology mainly through its ability to regulate angiogenesis 
and function of different immune cell types. Furthermore, PF-4 [19-23] as well as CTAP-III [19] have been shown to inhibit megakaryocytopoiesis. PF-4 also inhibits proliferation of erythroid and granulocyte/macrophage colonies $[20,24]$ and CD34+ progenitors via IL-8 interaction [25].

\section{CTAP-III physiology and function}

CTAP III is a major platelet ELR ${ }^{+}$CXC chemokine with molecular weight $9.3 \mathrm{kDa}$ [26]. It is produced not only by megakaryocytes but also by monocytes, lymphocytes and neutrophils $[27,28]$. CTAP-III, along with $\beta$ thromboglobulin $(\beta-\mathrm{TG})$, platelet basic protein (PBP) and neutrophil-activating peptide 2 (NAP-2, CXCL7) belongs to $\beta$-thromboglobulin-like proteins (Figure 1). CTAP-III is converted from a precursor PBP, the major megakaryocytes variant, during megakaryocyte maturation and platelet formation [29]. After its release from platelet $\alpha$-granules, CTAP-III can be proteolytically cleaved to $\beta$-TG $[26,30]$ and/or NAP-2 [31,32] with chemotactic activity [33]. The exact mechanism of the cleavage regulation is unknown. Although CTAP-III, $\beta$ TG and NAP-2 are all $\mathrm{NH}_{2}$-terminal truncated variants of the PBP precursor, each possesses a very distinct biological function. NAP-2 acts like a typical CXC chemokine while longer forms (PBP and CTAP-IlI) has no that activity [33]. The PBP gene is localized to 4q12-q13 in the vicinity PF-4 gene [7]. The manner in which CTAPIII stimulates connective tissue cells [26,34,35] and its immunoregulatory activity as a precursor of NAP-2 [31] are summarized in Table 1 .

\section{Platelet regulation of tumor angiogenesis and tumor growth}

Angiogenesis in adults play an important role in wound healing, female reproductive cycle but also in pathologic processes, such as diabetic retinopathy, cancer and other inflammatory disorders [41]. The process of angiogenesis is regulated by balance of positive and negative regulators. Platelet $\alpha$-granules contain both types of angiogenesis regulators and consequently, platelets are involved in tumor angiogenesis [42-44]. Positive regulators of angiogenesis include platelet-derived growth factor (PDGF), vascular endothelial growth factor (VEGF), fibroblast growth factor-2 (FGF-2) etc.; and angiogenesis inhibitors include PF-4, endostatin, thrombospondin-1 etc. [45]. Italiano et al. (2008) reported that angiogenic and antiangiogenic factors are stored in distinct sets of $\alpha$-granules and their release is regulated by selective activation of different thrombin receptors [46].

The role of PF-4 and CTAP-III in regulation of angiogenesis and within the tumor microenvironment is described in following paragraphs and the main features are summarized in Figure 2.

\section{PF-4, as an angiogenesis inhibitor}

PF-4 inhibits migration and proliferation [47,56,57] of endothelial cells (EC) and angiogenesis both in vitro [58] and in vivo $[57,59]$ via several mechanisms. Firstly, PF-4 binds positive angiogenesis regulators such as VEGF, bFGF and thus prevents their receptor binding and bFGF dimerization $[47,48,60,61]$. More specifically, PF-4 also impedes growth factor binding to its proteoglycan receptors by competition for heparin and heparan sulphate (HS) sites or by displacement growth factor from these sites $[47,48]$. Lasagni et al. (2003) has described PF-4 receptor CXCR3B, a variant of chemokine receptor CXCR3, which is expressed on microvascular endothelium and activated T-lymphocytes [62]. PF-4/CXCR3B signaling plays a role in transduction of apoptotic signal and inhibition of proliferation in endothelium $[62,63]$. A further mechanism of inhibition of endothelial cell growth and proliferation has recently been reported by Woller et al. (2008) showing that reactive oxygen radicals released from PF-4-activated monocytes are responsible for the induction of apoptosis in EC [64]. PF-4 also prevents entry of EC into S phase and DNA synthesis [56]. A PF-4 variant (CXCL4L1/PF4 var) differing from its native compound in three amino acids at the peptide carboxy-terminal part is even more potent angiogenesis inhibitor, and its role in cancer biology is reviewed by Vandercappellen et al. 2011 [65].

PF-4 also exerts its anti-angiogenic activity via inhibition of pro-angiogenic cytokine IL-8. IL-8, also a CXC chemokine family member, has been shown to enhance endothelial cell survival, proliferation, and production of matrix metalloproteinases which further stimulates tumor angiogenesis, and consequently tumor growth

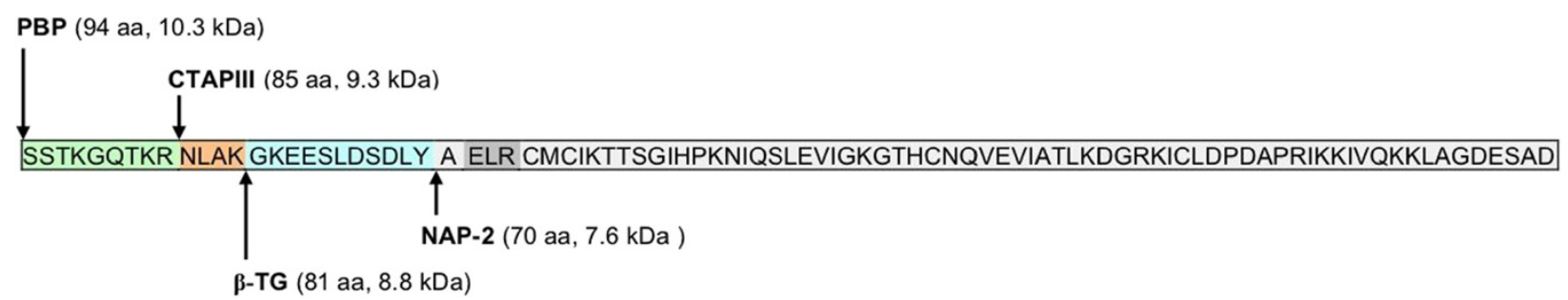

B-TG (81 aa, $8.8 \mathrm{kDa})$

Figure 1 Amino acid sequences of $\beta$-thromboglobulin-like proteins [36]. 
Table 1 CTAP III biological functions

\begin{tabular}{ll}
\hline Regulation of hematopoiesis & Inhibition of megakaryocytopoiesis [19] \\
Immunoregulatory activity & Histamine release by basophils [37] \\
& Precursor of NAP-2 [31] \\
Angiogenesis & Chemotaxis of EC in vitro [5] \\
Connective tissue cells & Mitogenesis [34] \\
metabolism & Glycolysis [34] \\
& Hyaluronic acid and GAGs \\
& Synthesis [22,34] \\
& Prostaglandin E2 secretion [22] \\
& Plasminogen activator synthesis [35] \\
Others & Stimulation of glucose transport [38] \\
& Transcellular mediator of the cellular \\
& sphingomyelin import [39] \\
Heparanase activity [40]
\end{tabular}

and metastasis [52]. IL-8 exhibits its signaling via CXCR2 receptor which is under normal conditions antagonized by PF-4 [50]. Moreover, PF-4/IL-8 heterodimers have stronger anti-proliferative activity on endothelial cells than PF-4 alone [49]. Inhibitory effect of recombinant PF-4 on tumor growth and metastasis $[66,67]$ is most likely consequence of tumor angiogenesis inhibition, because PF-4 does not inhibit proliferation of tumor cells in vitro [66]. Gene therapy by PF-4 gene transfer has also shown anticancer effect in vivo $[68,69]$.

\section{Regulation of tumor angiogenesis and tumor growth: connection with tumor microenvironment and the immune system}

Inflammation is the primary and likely the most important host protective reaction to tissue and cellular damage. However, many pathological processes including cancer may recruit inflammatory response. Immune cells are endowed with a dual role: as a defense mechanism, or as a supporter of tumor growth particularly by stimulation of EC and tumor neovascularization in a process referred to as "inflammatory angiogenesis". It is thought to be due changes within a tumor microenvironment that stimulates immune regulators to release cytokines and growth factors that lead to promotion of tissue remodeling, angiogenesis and tumor growth [70].

Although PF-4 belongs to the chemokine family it doesn't show significant chemotactic activity for neutrophils [36,70-72]. Yet, PF-4 is involved in regulation of other cell types through other mechanisms which involve complex spectrum of functions on immune cells as summarized in Table 2. Reports on the ability of PF-4 to stimulate innate immune response predominate suggesting that rather than using inflammation to stimulate tumor growth, PF-4 stimulates immune cancer surveillance and tumor inhibition.

\section{CTAP-III, as an angiogenesis modulator and stimulator of inflammation}

There is not much information about the role of CTAPIII in angiogenesis but expression studies suggest that CTAP-III plays an important role in tumor growth and progression. CTAP-III has been reported to mediate chemotaxis of EC in vitro and stimulate angiogenesis in vivo [5]. Of these various cleavage products of PBP, only CTAP III possesses heparanase activity rendering it a very distinct role in modulating tumor progression [53].

NAP-2/CXCL7, CTAP-III cleavage product, has been shown to stimulate angiogenesis in vivo [83]. NAP-2 also stimulates neutrophil degranulation leading to increased vascular permeability [84]. Together, CTAP-III and NAP2 collaborate in degrading heparin and heparan sulphate [40], important components of extracellular matrix and anchoring proteins for many heparin-binding regulators of angiogenesis. As the surface of inflammatory and endothelial cells in the tumor microenvironment expresses increased amounts of HS, local blood coagulation, fibrin deposition, cell adhesion and tumor growth are facilitated. Tang et al. 2008 reported that CXCL7 transfected breast cells acquired invasive properties and demonstrated elevated heparanase activity, which caused remodeling of extracellular matrix and facilitate cancer metastasis [53].

NAP-2 is formed through further cleavage of PBP and CTAP-III in the presence of leukocyte proteases [31,32,51]. While its precursors do not show pro-inflammatory activity, NAP-2 stimulates both chemotaxis and neutrophil degranulation through chemokine receptors CXCR-1 and CXCR-2 [33,51]. The amino-terminal residues of NAP-2 extended variants probably mask ELR motif, a crucial neutrophil receptor binding domain, leading to predominantly inhibitory chemokine activity [85]. However, it has been shown that continuous accumulation of NAP-2, as a product of PBP and CTAP-III proteolysis, results in antiinflammatory activity by desensitization of neutrophils through down-regulation of chemokine receptors, especially CXCR-2. This finding suggests that NAP-2 has dual function and that interaction of the various PBP cleavage products produces a very finely tuned system.

\section{PF-4 in clinical trials}

Clinical trials testing recombinant PF-4 have been completed in metastatic colon cancer [86], AIDS-related Kaposi's sarcoma $[87,88]$, metastatic melanoma, renal cell carcinoma [89] and high-grade glioma [90]. The phase I trial in patients with metastatic colorectal cancer evaluated 9 patients who had failed 5-FU treatment. Subjects received rPF-4 at doses ranging from 0.3 to $3.0 \mathrm{mg} / \mathrm{kg}$ via 30 -minute infusion, three additional patients were treated with the $3 \mathrm{mg} / \mathrm{kg}$ dose using a 6hour infusion. Of the 11 evaluable patients, rPF- 4 was well tolerated at the doses and schedules tested, but no 


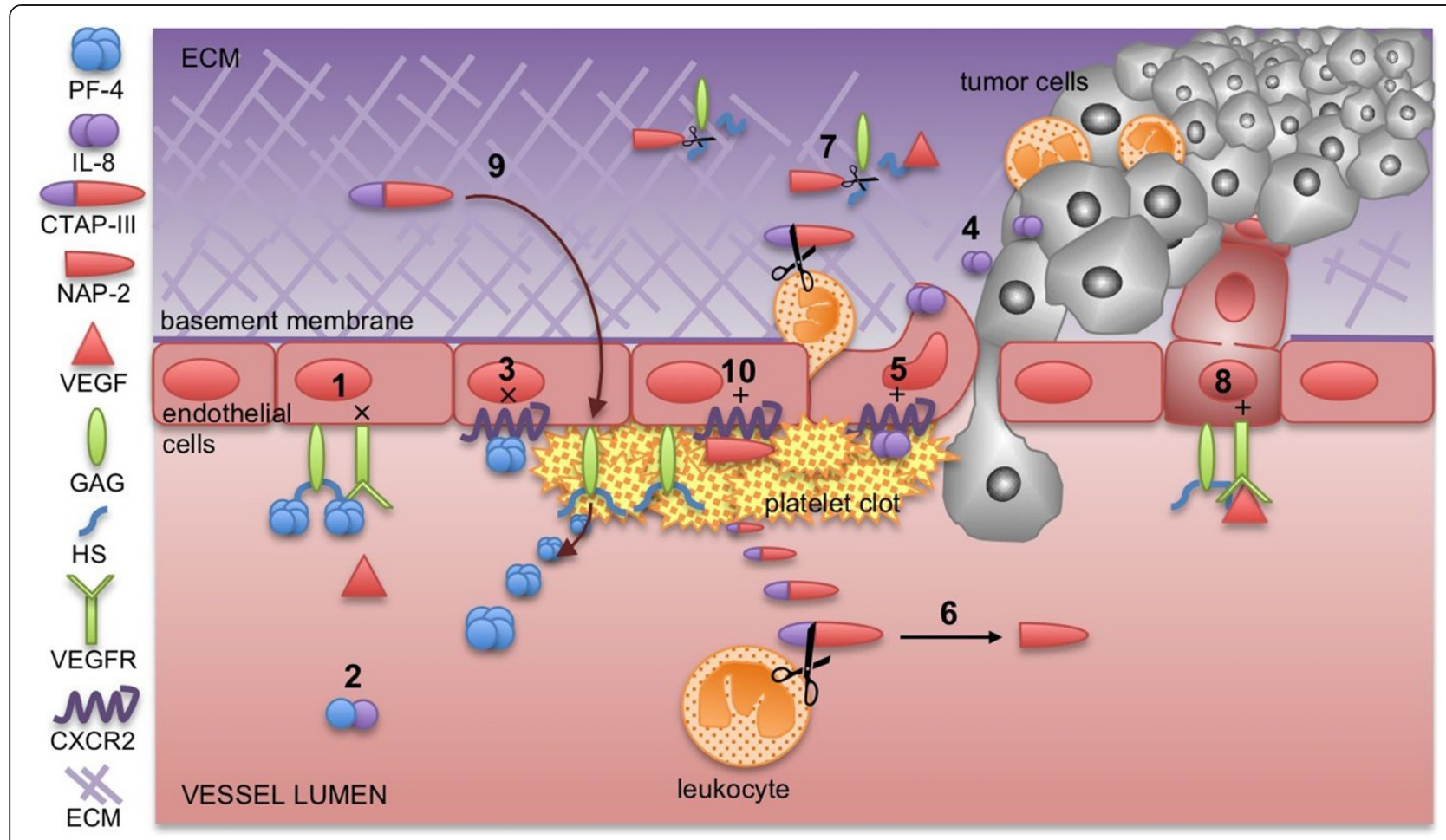

Figure 2 PF-4 and CTAP-III/NAP-2 connection and their role in tumor angiogenesis and progression. The interaction of various components of the wound or tumor stroma depends on the presence or absence of different tissue proteases and on the reciprocal interaction of the various cells. PF-4 inhibits angiogenesis by (1) competitive inhibition of pro-angiogenic growth factors binding to HS sites in the tissues, where HS serve as co-receptor of growth factor receptors, such as VEGFR2 [47,48]; (2) by binding of IL-8 to form PF-4/IL-8 heterodimers [49] (3) and by antagonising of CXCR2, IL-8 receptor, which is involved in regulation inflammation and angiogenesis [50]. (4) IL-8, released by tumor as well as stroma and endothelial cells, induces chemotaxis of inflammatory cells [51] and angiogenesis [52] (5) by signaling through CXCR2 receptor [52]. The CXCL7/CTAP-III acts in a number of different ways: (6) CTAP-III is cleaved by leukocyte proteases to NAP-2 [31,32]; (7) NAP-2 splits HS from glycosaminosulfates (GAG) in the stroma, leading to interruption of extracellular matrix (ECM) protein-protein interactions and release of heparan sulphate-bound growth factors, such as VEGF [40]. (8) The remodeled ECM at the side of inflammation and angiogenesis enables the interaction of the released growth factors (e.g. VEGF) with their respective receptors and leads to modulation of angiogenesis and regulation of tumor spreading [53]; (9) CTAP-III stimulates further GAG synthesis [54] on the surface of endothelial cell injury leading to increased PF-4 production and localization of heparin binding angiogenesis regulators. (10) NAP-2 regulates activity and expression of CXCR2 [51,55].

clinical responses to treatment rPF-4 were observed. Similar results were observed in phase I study of recombinant platelet factor 4 in patients with metastatic melanoma and renal cell carcinoma. Three dosage groups with 3 patients at each level of $0.3,1.0$ and $3.0 \mathrm{mg} / \mathrm{kg}$ were evaluated. Recombinant PF-4 was given as a 6-hour infusion on days 1, 8-10 and 15-19 and could be given in two 5 day courses on days 29-33 and 43-47. All patients completed the initial 9 doses and 4 completed the 19 additional doses. There was no hematopoietic, hepatic, renal or coagulation toxicity, and most of the symptoms were attributed to the underlying disease. No dose response was recorded. Six patients progressed and two were stable during the 7 week study period. The authors concluded that rPF-4 had no biological activity at the doses and schedules used.

These perceived failures may be due to the fact that PF-4, similarly to other biologic response modifiers, is a sensitizer to cytotoxic chemotherapy rather than a cytotoxic agent and its effect may not be detected in monotherapy setting. Furthermore, establishing a maximally tolerated dose of rPF-4 in phase I may be inappropriate. Most biologic response modifiers, rPF-4 included, have U-shaped response curves and maximum effect is achieved at mid-range. High doses lead to toxicities caused by undesirable (and unnecessary) off-target effects. Thus, the goal when using biologic response modifiers such as rPF-4 should be the determination of a biologically effective dose. However, establishing the optimal dose may be very difficult in absence of validated surrogate markers for its biological activity. At least for now, the choice of phase I trial designs and appropriate end points may need to be guided by the mechanism of action of the agent like rPF-4. Currently no phase II trials with rPF-4 have been continued.

\section{PF-4 and CTAP-III as biomarkers of tumor growth}

PF-4 and CTAP-III can be used as biomarkers of tumor growth $[1,10,91,92]$. Yee et al. (2009) identified higher 
Table 2 PF-4 biological functions

\begin{tabular}{ll}
\hline Procoagulant activity & Inhibition of heparin-dependent thrombin inactivation [15] \\
Anticoagulant activity & Inhibition of factor XII [16] and vitamin K dependent coagulation factors [17] \\
& Generation of activated protein C [18] \\
Regulation of hematopoiesis & Inhibition of megakaryocytopoiesis [19-24] \\
& Survival of hematopoietic and progenitor cells [73] \\
& Inhibition of BFU-E, CFU-GM and CD34+ progenitors proliferation [24,25] \\
& Stimulation of neutrophil adhesion and secondary granule exocytosis [36,71,72,74] \\
Immunoregulatory activity & Stimulation of monocyte adhesion and activation [64,75,76] \\
& Induction of monocyte differentiation into macrophage [77] and APC [78] \\
& Stimulation of eosinophil adhesion [79] \\
& Stimulation of histamine release by basophils [80] \\
& Activation of NK cells and IL-8 release [81] \\
& Inhibition of T-cell activation and proliferation [82] \\
& Growth factors (VEGF, bFGF) binding [47,48,60] \\
Competition with growth factors (VEGF, bFGF) for glycosaminoglycan (GAGs) binding [47,48] & Prevention of EC entry into S phase and inhibition of DNA synthesis [56] \\
Anti-angiogenic activity & Monocyte ROS mediated cytotoxicity for EC [64]
\end{tabular}

serum levels of CTAP-III in pulmonary venous than in arterial blood using mass spectrometry (MS) and immunoassay [93]. While the levels of CTAP-III decreased after curative surgical resection, the elevated levels did not decrease in patients with residual disease after resection. Elevated blood levels of CTAP-III were detectable for up to 29 months before clinical diagnosis of lung cancer [93]. Increased levels of plasma CTAP-III were also detected using MS and ELISA in patients with lung cancer [94].

Grisaru et al. (2000) studied tissue expression of CTAPIII in cervical cancer specimens using immunostaining [95]. In normal epithelium CTAP-III was distributed in all of the epithelial layers, except in the highly active and proliferating basal cells. Cells of invasive cervical carcinoma did not stain for CTAP-III, and the presence of CTAP-III was limited to endothelial cells of capillary blood vessels. Moreover, CTAP-III staining pattern correlated positively with the degree of epithelial cell differentiation and with the stage of CIN [95] suggesting the role of CTAP-III in tumor progression and angiogenesis.

As it appears, PF-4 is concentrated in platelets and little is detected in plasma [91,92]. Platelet levels of PF-4 as determined by surface-enhanced laser desorption/ ionization time-of-flight MS (SELDI TOF MS) are upregulated following implantation of human tumor xenografts in mice but fall in tumor progression. In contrast, the levels of PF-4 in plasma remained unchanged $[1,91,92]$. We had proposed that elevated platelet levels in tumor-bearing mice present feedback loop mechanism in response to the induction of pro-angiogenic factors by the growing tumor [91]. Study in patients with early colorectal cancer showed statistically significant increase in PF-4 in platelets coincident with a rise in pro-angiogenic factors, such as VEGF and PDGF, compared to healthy controls, while changes in plasma levels of PF-4 remained insignificant [92]. It is likely that PF-4 rather than being released from platelets in circulation, binds locally to the HS at sites of platelet adhesion.

\section{Conclusions}

Until recently, PF-4 has been studied in the past mainly in the setting of heparin-induced thrombocytopenia. The clinical translation of its biological effects in suppression of tumor growth, prevention of atherosclerotic plague, endometriosis, chronic inflammation and other angiogenesis-dependent diseases may have been hindered by a lack of understanding of its biological effects and mechanism of action. We have summarized emerging data on role of PF-4 and CTAP-III in regulation of tumor growth. It appears that the role of these two chemokines in modulation of tumor dynamics cannot be separated from the role of platelets and inflammation within the tumor microenvironment. While much of the biology of platelet-associated PF-4 and CTAP-III is likely to be harnessed with therapeutic intent only in the future, an obvious immediate clinical application may be to use them as biomarkers of cancer presence and/or therapeutic response. The more conventional biological samples such as serum or plasma have certainly not lead to emergence of any reliable biomarker. However, since angiogenesis regulators are sequestered in platelets, measurement of these chemokines in platelets may give a much better reflection of the actual angiogenic 
process. Finally, PF-4 is a locally acting protein whose role is to modulate the stroma of the wound or the tumor and its systemic administration may not ensure its bioavailability within the respective microenvironment. Perhaps the delivery of a recombinant PF-4 via platelets as its natural vehicle may provide a more biologically relevant treatment modality and improve its therapeutic potential.

\section{Competing interests}

The authors declare that they have no competing interests.

\section{Authors' contributions}

KP drafted chapters "introduction", "PF-4 physiology and function CTAP-III physiology and function" and "Platelet regulation of tumor angiogenesis and tumor growth"; prepared tables and figures; formatted references. KG drafted chapters "PF-4 and CTAP-III as biomarkers of tumor growth". RD drafted chapter "PF-4 in clinical trials". BB drafted chapter "PF-4, as an angiogenesis inhibitor"; contributed to table 2 preparation. GLK drafted chapter "CTAP-III, as an angiogenesis modulator and stimulator of inflammation"; revised manuscript. LZD came up with an idea and design of the manuscript; drafted chapter "Regulation of tumor angiogenesis and tumor growth connection with tumor microenvironment and the immune system" and "conclusions"; finalized the manuscript. All authors read and approved the final manuscript.

\section{Acknowledgment}

This work was supported by European Regional Development Fund and the State budget of the Czech Republic for Regional Centre of Applied Molecular Oncology (RECAMO, CZ.1.05/2.1.00/03.0101).

\section{Author details}

Department of Laboratory Medicine, Masaryk Memorial Cancer Institute, Zluty kopec 7, Brno 656 53, Czech Republic. Department of Clinical Evaluation, Masaryk Memorial Cancer Institute, Zluty kopec 7, Brno 65653 , Czech Republic. ${ }^{3}$ Clinic of Comprehensive Cancer Care, Masaryk Memorial Cancer Institute, Zluty kopec 7, Brno 656 53, Czech Republic. ${ }^{4}$ Center of Cancer Systems Biology, Steward St. Elizabeth's Medical Center Pediatric Hematology Oncology, Tufts University School of Medicine, Boston, MA, USA. ${ }^{5}$ Department of Pharmacology, Medical Faculty, Masaryk University, Kamenice 5, Brno 625 00, Czech Republic. ${ }^{6}$ Regional Centre for Applied Molecular Oncology, Masaryk Memorial Cancer Institute, Zluty kopec 7, Brno 656 53, Czech Republic.

Received: 6 May 2013 Accepted: 13 June 2013

Published: 24 June 2013

\section{References}

1. Klement GL, Yip TT, Cassiola F, Kukuchi L, Cervi D, Podust V, Italiano JE, Wheatley E, Abou-Slaybi A, Bender E, Almog N, Kieran MW, Folkman J: Platelets actively sequester angiogenesis regulators. Blood 2009, 130:2835-2842.

2. Von Hundelshausen P, Petersen F, Brandt E: Platelet-derived chemokines in vascular biology. Thromb Haemost 2007, 97:704-713.

3. Belperio JA, Keane MP, Arenberg DA, Addison CL, Ehlert JE, Burdick MD, Strieter RM: CXC chemokines in angiogenesis. J Leukoc Biol 2000, 68:1-8.

4. Fivenson DP, Faria DT, Nickoloff BJ, Poverini PJ, Kunkel S, Burdick M, Strieter RM: Chemokine and inflammatory cytokine changes during chronic wound healing. Wound Repair Regen 1997, 5:310-322.

5. Strieter RM, Polverini PJ, Kunkel SL: The functional role of the ELR motif in CXC chemokine-mediated angiogenesis. J Biol Chem 1995, 270:27348-27357.

6. Deuel TF, Keim PS, Farmer M, Heinrikson RL: Amino acid sequence of human platelet factor 4. Proc Natl Acad Sci USA 1977, 74:2256-2258.

7. Tunnaclife A, Majumdar S, Yan B, Poncz M: Genes for beta-thromboglobulin and platelet factor 4 are closely linked and form part of a cluster of related genes on chromosome 4. Blood 1992, 79:2896-2900.
8. Ryo R, Nakeff A, Huang SS, Ginsberg M, Deuel TF: New synthesis of a platelet-specific protein: platelet factor 4 synthesis in a megakaryocyteenriched rabbit bone marrow culture system. J Cell Biol 1983, 96:515-520.

9. Barber AJ, Käser-Glanzmann R, Jakábová M, Luscher EF: Characterization of a chondroitin 4-sulfate proteoglycan carrier for heparin neutralizing activity (platelet factor 4) released from human blood platelets. Biochem Biophys Acta 1972, 286:312-329.

10. Peterson JE, Zurakowski D, Italiano JE Jr, Michel LV, Fox L, Klement GL, Folkman J: Normal ranges of angiogenesis regulatory proteins in human platelets. Am J Hematol 2010, 85:487-493.

11. Zucker B, Katz R: Platelet factor 4: production, structure, and physiologic and immunologic action. Proc Soc Exp Biol Med 1991, 198:693-702.

12. Kaper B, Petersen F: Molecular pathways of platelet factor $4 / C X C L 4$ signaling. Eur J Cell Biol 2011, 90:521-526.

13. Files JC, Malpass TW, Yee EK, Ritchie JL, Harker LA: Studies of human plate alpha-granule release in vivo. Blood 1981, 58:607-618.

14. Gerotziafas GT, Elalamy I, Lecrubier C, Lebrazi J, Mirshahi M, Potevin F, Lecompte T, Samama MM: The role of platelet factor 4 in platelet aggregation induced by the antibodies implicated in heparin-induced thrombocytopenia. Blood Coagul Fibrinolysis 2001, 12:511-520.

15. Piepkorn MW: Dansyl (5-dimethylaminonaphthalene-1-sulphonyl)-heparin binds antithrombin III and platelet factor 4 at separate sites. Biochem J 1981, 196:649-651.

16. Dumenco LL, Everson B, Culp LA, Ratnoff OD: Inhibition of the activation of Hageman factor (factor XII) by platelet factor 4. J Lab Clin Med 1988, 112:394-400.

17. Yang L, Rezaie AR: Calcium-binding sites of the thrombin-thrombomodulin -protein C complex: possible implications for the effect of platelet factor 4 on the activation of vitamin K-dependent coagulation factors. Thromb Haemost 2007, 97:899-906.

18. Slungaard A, Fernandez JA, Griffin JH, Key NS, Long JR, Piegors DJ, Lentz SR: Platelet factor 4 enhances generation of activated protein $C$ in vitro and in vivo. Blood 2003, 102:146-151.

19. Han ZC, Bellucci S, Walz A, Baggiolini M, Caen JP: Negative regulation of human megakaryocytopoiesis by human platelet factor 4 (PF4) and connective tissue-activating peptide (CTAP-III). Int J Cell Cloning 1990, 8:253-259.

20. Han ZC, Sensébe L, Abgrall JF, Brière J: Platelet factor 4 inhibits human megakaryocytopoiesis in vitro. Blood 1990, 75:1234-1239.

21. Lambert MP, Rauova L, Bailey M, Sola-Visner MC, Kowalska MA, Poncz M: Platelet factor 4 is a negative autocrine in vivo regulator of megakaryopoiesis: clinical and therapeutic implications. Blood 2007, 110:1153-1160.

22. Lambert MP, Wang Y, Bdeir KH, Nguyen Y, Kowalska MA, Poncz M: Platelet factor 4 regulates megakaryopoiesis through low-density lipoprotein receptor-related protein 1 (LRP1) on megakaryocytes. Blood 2009, 114:2290-2298.

23. Lambert MP, Xiao L, Nguyen Y, Kowalska MA, Poncz M: The role of platelet factor 4 in radiation-induced thrombocytopenia. Int J Radiat Oncol Biol Phys 2011, 80:1533-1540.

24. Lecomte-Raclet L, Alemany M, Sequeira-Le Grand A, Amiral J, Quentin G, Vissac AM, Caen JP, Han ZC: New insights into the negative regulation of hematopoiesis by chemokine platelet factor 4 and related peptides. Blood 1998, 91:2772-2780.

25. Dudek AZ, Nesmelova I, Mayo K, Verfaillie CM, Pitchford S, Slungaard A: Platelet factor 4 promotes adhesion of hematopoietic progenitor cells and binds IL-8: novel mechanisms for modulation of hematopoiesis. Blood 2003, 101:4687-4694.

26. Castor CW, Miller JW, Walz DA: Structural and biological characteristics of connective tissue activating peptide (CTAP-III), a major human platelet-derived growth factor. Cell Biol 1983, 80:765-769.

27. El-Gedaily A, Schoedon G, Schneemann M, Schaffner A: Constitutive and regulated expression of platelet basic protein in human monocytes. $J$ Leukoc Biol 2004, 75:495-503.

28. Lida N, Haisa M, Igarashi A, Pencev D, Grotendorst GR: Leukocyte-derived growth factor links the PDGF and CXC chemokine families of peptides. FASEB J 1996, 10:1336-1345.

29. Deutsch V, Bitan M, Friedmann Y, Eldor A, Vlodavsky I: Megakaryocyte maturation is associated with expression of the CXC chemokine connective tissue-activating peptide CTAP III. Br J Haematol 2000, 111:1180-1189. 
30. Resmi KR, Krishnan LK: Protease action and generation of betathromboglobulin-like protein followed by platelet activation. Thromb Res 2002, 106:229-236.

31. Schiemann F, Grimm TA, Hoch J, Gross R, Lindner B, Petersen F, Bulfone-Paus S, Brandt E: Mast cells and neutrophils proteolytically activate chemokine precursor CTAP-III and are subject to counterregulation by PF-4 through inhibition of chymase and cathepsin G. Blood 2006, 107:2234-2242.

32. Walz A, Baggioloni M: Generation of the neutrophil-activating peptide NAP-2 from platelet basic protein or connective tissue-activating peptide III through monocyte proteases. J Exp Med 1990, 171:449-454.

33. Walz A, Dewald B, von Tscharner V, Baggiolini M: Effects of the neutrophil-activating peptide NAP-2, platelet basic protein, connective tissue-activating peptide III and platelet factor 4 on human neutrophils. J Exp Med 1989, 170:1745-1750.

34. Castor CW, Ritchie JC, Williams CH Jr, Scott ME, Whitney SL, Myers SL, Sloan TB, Anderson BE: Connective tissue activation. XIV. Composition and actions of a human platelet autacoid mediator. Arthritis Rheum 1979 22:260-272.

35. Ragsdale CG, Castor CW, Roberts DJ, Swartz KH: Connective tissue activating peptide III. Induction of synthesis and secretion of plasminogen activator by synovial fibroblasts. Arthritis Rheum 1984, 27:663-667.

36. Brandt E, Petersen F, Ludwig A, Ehlert JE, Bock L, Flad HD: The betathromboglobulins and platelet factor 4: blood platelet derived CXC chemokines with divergent roles in early neutrophil regulation. J Leukoc Biol 2000, 67:471-478.

37. Proudfoot AE, Peitsch MC, Power CA, Allet B, Mermod JJ, Bacon K, Wells TN: Structure and bioactivity of recombinant human CTAP-III and NAP-2. J Protein Chem 1997, 16:37-49.

38. Tai PK, Liao JF, Hossler PA, Castor CW, Carter-Su C: Regulation of glucose transporters by connective tissue activating peptide-III isoforms. J Biol Chem 1992, 267:19579-19586

39. Stoeckelhuber M, Dobner $\mathrm{P}$, Baumgärtner $\mathrm{P}$, Ehlert J, Brandt E, Mentele $\mathrm{R}$ Adam D, Engelmann B: Stimulation of cellular sphingomyelin import by the chemokine connective tissue-activating peptide III. J Biol Chem 2000, 275:37365-37372.

40. Hoogewerf AJ, Leone JW, Reardon IM, Howe WJ, Asa D, Heinrikson RL, Ledbetter SR: CXC chemokines connective tissue activating peptide-III and neutrophil activating peptide- 2 are heparin/heaparan sulfate-degrading enzymes. J Biol Chem 1995, 7:3268-3277.

41. Pandya NM, Dhalla NS, Santani DD: Angiogenesis-a new target for future therapy. Vascul Pharmacol 2006, 44:265-274

42. Gasic GJ, Gasic TB, Stewart CC: Antimetastatic effects associated with platelet reduction. Proc Natl Acad Sci USA 1968, 61:46-52.

43. Karpatkin S, Ambrogio C, Pearlstein E: The role of tumor-induced platelet aggregation, platelet adhesion and adhesive proteins in tumor metastasis. Prog Clin Biol Res 1988, 283:585-606.

44. Pinedo HM, Verheul HM, D'Amato RJ, Folkman J: Involvement of platelets in tumour angiogenesis? Lancet 1998, 352:1775-1777.

45. Gay LJ, Felding-Habermann B: Contribution of platelets to tumour metastasis. Nat Rev Cancer 2011, 11:123-134.

46. Italiano JE, Richardson JL, Patel-Hett S, Battinelli E, Zaslavsky A, Short S, Ryeom S, Folkman J, Klement GL: Angiogenesis is regulated by a novel mechanism: pro- and antiangiogenic proteins are organized into separate a-granules and differentially released. Blood 2008, 111:1227-1233.

47. Perollet C, Han ZC, Savona C, Caen JP, Bikfalvi A: Platelet factor-4 modulates fibroblast growth factor 2 (FGF2) activity and inhibits FGF2 dimerization. Blood 1998, 91:3289-3299.

48. Gengrinowitch S, Greenberg SM, Cohen T, Gitay-Goren H, Rockwell P, Maione TE, Levi BZ, Neufeld G: Platelet factor-4 inhibits the mitogenic activity of VEGF121 and VEGF165 using several concurrent mechanisms. J Biol Chem 1995, 270:15059-15065

49. Nesmelova IV, Sham Y, Dudek AZ, van Eijk LI, Wu G, Slungaard A, Mortari F, Griffioen AW, Mayo KH: Platelet factor 4 and interleukin-8 CXC chemokine heterodimer formation modulates function at the quaternary structural level. J Biol Chem 2005, 280:4948-4958.

50. Jones SA, Dewald B, Clark-Lewis I, Baggiolini M: Chemokine antagonists that discriminate between interleukin- 8 receptors. Selective blockers of CXCR2. J Biol Chem 1997, 272:16166-16169.
51. Ehlert JE, Ludwig A, Grimm GA, Lindner B, Flad HD, Brandt E: Down-regulation of neutrophil functions by the ELR(+) CXC chemokine platelet basic protein. Blood 2000, 96:2965-2972

52. Li A, Dubey S, Varney ML, Dave BJ, Singh RK: IL-8 directly enhances endothelial cell survival, proliferation, and matrix metalloproteinases production and regulated angiogenesis. J Immunol 2003, 170:3369-3376.

53. Tang Z, Yu M, Miller F, Berk RS, Tromp G, Kosir MA: Increased invasion through basement membrane by CXCL7-transfected breast cells. Am J Surg 2008, 196:690-696.

54. Castor CW, Whitney SL: Connective tissue activation. XIII. Stimulation of sulfated glycosaminoglycans synthesis in human connective tissue cells by peptide mediators from lymphocytes and platelets. J Lab Clin Med 1978, 91:811-821.

55. Hristov M, Zernecke A, Bidzhekov K, Liehn EA, Shagdarsuren E, Ludwig A Weber C: Importance of CXC chemokine receptor 2 in the homing of human peripheral blood endothelial progenitor cells to sites of arterial injury. Circ Res 2007, 100:590-597.

56. Grupta SK, Singh JP: Inhibition of endothelial cell proliferation by platelet factor-4 involves a unique action on S phase progression. J Cell Biol 1994, 127:1121-1127.

57. Yang L, Du J, Hou J, Jiang H, Zou J: Platelet factor-4 and its p17-70 peptide inhibit myeloma proliferation and angiogenesis in vivo. BMC Cancer 2011, 11:s261.

58. Jouan V, Canron X, Alemany M, Caen JP, Quentin G, Plouet J, Bikfalvi A Inhibition of in vitro angiogenesis by platelet factor-4-derived peptides and mechanism of action. Blood 1999, 94:984-993.

59. Maione TE, Gray GS, Petro J, Hunt AJ, Donner AL, Bauer SI, Carson HF, Sharpe RJ: Inhibition of angiogenesis by recombinant human platelet factor-4 and related peptides. Science 1990, 247:77-79.

60. Chadderton NS, Stringer SE: Interaction of platelet factor 4 with fibroblast growth factor 2 is stabilised by heparan sulphate. Int J Biochem Cell Biol 2003, 35:1052-1055.

61. Lozano RM, Redondo-Horcajo M, Jiménez MÁ, Zilberberg L, Cuevas $P$, Bikfalvi A, Rico M, Giménez-Gallego G: Solution structure and interaction with basic and acidic fibroblast growth factor of a 3-kDa human platelet factor-4 fragment with antiangiogenic aktivity. J Biol Chem 2001, 276:35723-35734.

62. Lasagni L, Francalanci M, Annunziato F, Lazzeri E, Giannini S, Cosmi L, Sagrinati C, Mazzinghi B, Orlando C, Maggi E, Marra F, Romagnani S, Serio $M$, Romagnani P: An alternatively spliced variant of CXCR3 mediates the inhibition of endothelial cell growth induced by IP-10, Mig, and I-TAC, and acts as functional receptor for platelet factor 4. J Exp Med 2003 197:1537-1549.

63. Struyf S, Sologni L, Burdick MD, Vandercappellen J, Gouwy M, Noppen S, Proost P, Opdenakker G, Parmentier M, Gerard C, Sozzani S, Strieter RM, Van Damme J: Angiostatic and chemotactic activities of the CXC chemokine CXCL4L1 (platelet factor-4 variant) are mediated by CXCR3. Blood 2011, 117:480-488.

64. Woller G, Brandt E, Mittelstädt J, Rybakowski C, Petersen F: Platelet factor 4/CXCL4-stimulated human monocytes induce apoptosis in endothelial cells by the release of oxygen radicals. J Leukoc Biol 2008, 83:936-945.

65. Vandercappellen J, Van Damme J, Struyf S: The role of the CXC chemokines platelet factor-4 (CXCL4/PF-4) and its variant (CXCL4L1/PF-4var) in inflammation, angiogenesis and cancer. Cytokine Growth Factor Rev 2011 22:1-18.

66. Sharpe RJ, Byers HR, Scott CF, Bauer SI, Maione TE: Growth inhibition of murine melanoma and human colon carcinoma by recombinant human platelet factor 4. J Natl Cancer Inst 1990, 82:848-853.

67. Kolber DL, Knisely TL, Malone TE: Inhibition of development of murine melanoma lung metastases by systemic administration of recombinant platelet factor 4. J Natl Cancer Inst 1995, 15:304-309.

68. Tanaka T, Manome Y, Wen P, Kufe DW, Fine HA: Viral vector-mediated transduction of a modified platelet factor 4 cDNA inhibits angiogenesis and tumor growth. Nat Med 1997, 3:437-442.

69. Yamaguchi K, Ogawa K, Katsube T, Shimao K, Konno S, Shimakawa T, Yoshimatsu K, Naritaka Y, Yagawa H, Hirose K: Platelet factor 4 gene transfection into tumor cells inhibits angiogenesis, tumor growth and metastasis. Anticancer Res 2005, 25:847-852

70. Noonan DM, De Lerma Barbaro A, Vannini N, Mortara L, Albini A: Inflammation, inflammatory cells and angiogenesis: decisions and indecisions. Cancer Metastasis Rev 2008, 27:31-40. 
71. Petersen F, Bock LA, Flad HD, Brandt E: Chondroitin sulfate proteoglycan on human neutrophils specifically binds platelet factor 4 and is involved in cell activation. J Immunol 1998, 161:4347-4355.

72. Petersen F, Bock L, Flad HD, Brandt E: Platelet factor 4-induced neutrophil-endothelial cell interaction: involvement of mechanisms and functional consequences different from those elicited by interleukin-8. Blood 1999, 94:4020-4028.

73. Han ZC, Lu M, Li J, Defard M, Boval B, Schlegel N, Caen JP: Platelet factor 4 and other CXC chemokines support the survival of normal hematopoietic cells and reduce the chemosensitivity of cells to cytotoxic agents. Blood 1997, 89:2328-2335.

74. Clark-Lewis I, Dewald B, Geiser T, Moser B, Baggiolini M: Platelet factor 4 binds to interleukin 8 receptors and activates neutrophils when its $\mathrm{N}$ terminus is modified with Glu-Leu-Arg. Proc Natl Acad Sci USA 1993, 90:3574-3577.

75. von Hundelshausen P, Koenen RR, Sack M, Mause SF, Adriaens W, Proudfoot AE: Heterophilic interactions of platelet factor 4 and RANTES promote monocyte arrest on endothelium. Blood 2005, 105:924-930.

76. Pervushina O, Scheuerer B, Reiling N, Behnke L, Schröder JM, Kasper B, Brandt E: Platelet factor 4/CXCL4 induces phagocytosis and the generation of reactive oxygen metabolites in mononuclear phagocytes independently of $\mathrm{Gi}$ protein activation or intracellular calcium transients. J Immunol 2004, 173:2060-2067.

77. Scheuerer B, Ernst M, Dürrbaum-Landmann I, Fleischer J, Grage-Griebenow $\mathrm{E}$ : The CXC-chemokine platelet factor 4 promotes monocyte survival and induces monocyte differentiation into macrophages. Blood 2000, 95:1158-1166

78. Fricke I, Mitchell D, Petersen F, Böhle A, Bulfone-Paus S, Brandau S: Platelet factor 4 in conjunction with IL-4 directs differentiation of human monocytes into specialized antigenpresenting cells. FASEB J 2004, 18:1588-1590

79. Hayashi N, Chihara J, Kobayashi Y, Kakazu T, Kurachi D, Yamamoto T, Nakajima S: Effect of platelet-activating factor and platelet factor 4 on eosinophil adhesion. Int Arch Allergy Immunol 1994, 104(Suppl 1):57-59.

80. Brindley LL, Sweet JM, Goetzl EJ: Stimulation of histamine release from human basophils by human platelet factor 4. J Clin Incest 1983, 72:12181223.

81. Marti F, Bertran E, Llucià M, Villén E, Peiró M, Garcia J, Rueda F: Platelet factor 4 induces human natural killer cells to synthesize and release interleukin-8. J Leukoc Biol 2002, 72:590-597.

82. Fleischer J, Grage-Griebenow E, Kasper B, Heine H, Ernst M, Brandt E, Flad $H D$, Petersen F: Platelet factor 4 inhibits proliferation and cytokine release of activated human T cells. J Immunol 2002, 169:770-777.

83. Powell JA Jr, Mousa SA: Neutrophil-activating protein-2- and interleukin-8 -mediated angiogenesis. J Cell Biochem 2007, 102:412-420.

84. Osselaer NV, Damme JV, Rampart M, Herman AG: Increased microvascular permeability in vivo in response to intradermal injection of neutrophilactivating protein (NAP-2) in rabbit skin. Am J Pathol 1991, 13:23-27.

85. Malkowski MG, Lazar JB, Johnson PH, Edwards BF: The amino-terminal residues in the crystal structure of connective tissue activating peptide-III (des10) block the ELR chemotactic sequence. J Mol Biol 1997, 226:367-380.

86. Belman N, Bonnem EM, Harvey HA, Lipton A: Phase I trial of recombinant platelet factor 4 (rPF4) in patients with advanced colorectal carcinoma. Invest New Drugs 1996, 14:387-389.

87. Kahn J, Ruiz R, Kerschmann R, Berger T, Ma R, Coleman R, Alford BL: A phase $1 / 2$ study of recombinant plateler factor 4 (rPF4) in patients with AIDS related Kaposi's sarcoma (KS) [abstract]. Proc Am Soc Clin Oncol 1993, 12:s50.

88. Northfelt DW, Robles R, Lang W, Wagner B, Kahn J, Bonnem E: Phase I/II study of intravenous (IV) recombinant platelet factor 4 (rPF4) in AIDS-related Kaposi's sarcoma (AIDS-KS) [abstract]. Proc Am Soc Clin Oncol 1995, 14:s288.

89. Hersh EM, Wiggins CE, Crook LI, Bonem EM: Phase I study of recombinant platelet factor 4 (rPF4) in patients with metastatic melanoma and renal cell carcinoma [abstract]. Proc Am Soc Clin Oncol 1995, 14:5488.

90. Dinapoli RP, Buckner JC, Rydberg CH, Mullan BP, Davis DH: Phase I-II study of localized injection of recombinant platelet factor 4 (rPF4) in patients (pts) with recurrent high-grade glioma [abstract]. Proc Am Soc Clin Oncol 1995.

91. Cervi D, Yip TT, Bhattacharya N, Podust VN, Peterson J, Abou-Slaybi A, Naumov GN, Bender E, Almog N, Italiano JE Jr, Folkman J, Klement GL: Platelet-associated PF-4 as a biomarker of early tumor growth. Blood 2008, 111:1201-1207.
92. Peterson JE, Zurakowski D, Italiano JE Jr, Michel LV, Connors S, Oenick M, D'Amato RJ, Klement GL, Folkman J: VEGF, PF4 and PDGF are elevated in platelets of colorectal cancer patients. Angiogenesis 2012, 15:265-273.

93. Yee J, Sadar MD, Sin DD, Kuzyk M, Xing L, Kondra J, McWilliams A, Man SF, Lam S: Connective tissue-activating peptide III: a novel blood biomarker for early lung cancer detection. J Clin Oncol 2009, 27:2787-2792.

94. Lee G, Gardner BK, Elashoff DA, Purcell CM, Sandha HS, Mao JT, Krysan K, Lee JM, Dubinett SM: Elevated levels of CXC chemokine connective tissue activating peptide (CTAP)-III in lung cancer patients. Am J Trans/ Res 2011, 3:226-233

95. Grisaru D, Vlodavsky I, Prus D, Levavi H, Lessing JB, Eldor A, Friedmann Y: Connective tissue activating peptide III expression disappears progressively with increased dysplasia in human cervical epithelium. Gynecol Oncol 2000, 79:23-27.

doi:10.1186/1756-8722-6-42

Cite this article as: Pilatova et al.: Role of platelet chemokines, PF-4 and CTAP-III, in cancer biology. Journal of Hematology \& Oncology 2013 6:42.

\section{Submit your next manuscript to BioMed Central and take full advantage of:}

- Convenient online submission

- Thorough peer review

- No space constraints or color figure charges

- Immediate publication on acceptance

- Inclusion in PubMed, CAS, Scopus and Google Scholar

- Research which is freely available for redistribution

Submit your manuscript at www.biomedcentral.com/submit
C) BioMed Central 